\title{
Role of Accounting Standards for the Future of Islamic Financial Institutions
}

\author{
Dr. Faran Ahmad Qadri \\ Department of Accounting, College of Business, \\ King Abdulaziz University, Rabigh - 21911, Saudi Arabia
}

\begin{abstract}
One of the most important challenges faced by the Islamic financial Institutions (IFI's) is ensuring that financial statements are properly presented. The IFI's prepare financial statements under different accounting standards which results in the problem of reliability, comparability, understanding and transparency. The Accounting and Auditing Organization for Islamic Financial Institutions (AAOIFI) have taken a right step in developing the accounting and sharia standards for the IFI's. Against such a backdrop, this paper analyses whether there is requirement for specific Islamic accounting standards to make financial institution's practices compliant with the Islamic Standards. This paper also analyses the role of AAOIFI in developing the accounting, auditing and ethical standards asper the sharia principle.
\end{abstract}

Keywords: AAOIFI, Accounting Standards, Financial Statement, IFI's, Interest, Islamic Financial Institutions, Sharia Accounting

DOI: $10.7176 / \mathrm{RJFA} / 10-22-12$

Publication date: November $30^{\text {th }} 2019$

\section{Introduction:}

Recently we have been witnessing that the need for Islamic finance has been overwhelmingly growing at fastest speed around the globe in general and in Islamic world specifically. It has not been developing only in the Islamic countries but also developing rapidly in the Muslim minority countries. This is the world-wide phenomenon centered around the Malaysia, Bahrain and United Kingdom (Maurer 2002). The objective behind establishing Islamic Financial Institutions is to safeguard the Muslims from paying and receiving interest (riba) as interest is strictly prohibited by Islam. Shari'ah which is really considered as the way of life and derived from the Qur'an and Sunnah. As a Muslim every act we do should be accountable to God and it is applicable to the economic transactions also. If we think that we are accountable to God means we consider our economic transaction as a worship and seeking a return from God in here and hereafter. Therefore, Islamic Financial Institutions are different from the conventional financial institutions regarding purposes, traditions, approaches (Rashid et. Al. 2011). There are many factors which determines the adoption of accounting standards for an organization namely, legal, political, tax structure, internal and external factors (Cooke \& Wallace, 1990; Elliot \& Elliot, 2007; Nobes \& Parker, 2012).

This study contains 5 sections as follows:

1. Concept of Islamic Accounting.

2. Islamic Accounting and Conventional accounting comparison.

3. Recent developments in Islamic Accounting.

4. AAOIFI and Its Role in Development of Islamic Accounting.

5. Conclusion and Recommendations.

\section{Concept of Islamic Accounting:}

Islamic accounting can be defined as recording of finacial transactions by the Islamic financial institutions or individuals in accordance with sharia or accrding the principles laid down by the sharia or Islamic law. Accounting in Islam is the moral code of conduct without the imagination of (riba) interest. Interest is strictly prohibited in Islam. Islamic Accounting is based on the two basic principles.

- Equal Distribution of Wealth and

- Social Justice

Equal distribution of wealth is the beautiful thing in Islam. It means that the efforts are to be made to distribute the resources equally among the stakeholders. It has been seen that most of resources are held by the rich people and consequently, gulf between rich and poor is increasing. Justice is to be maintained under all the circumstances within the society. It must be ensured in the finance world that everything is recorded asper the rules and principles laid down by the sharia. Islamic accounting prohibits exploitation of one group by the other. Accounting in Qur'an: Allah says in holy Quran (Surah Al-Baqarah 282). O who have believed, if you make a transaction with anyone, write it even if you have no writing skills. Similarly those who have writing skills should not refuse to write as Allah has guided him and fear Allah, Allah knows everything.

This ayah and many other ayah in holy Quran (Surah Baqarah 42, 282, 283, Surah Al-Haqqah:51, Surah Al 
Hujurat 51, and Surah Al Isra 34)) has emphasized the importance of accounting and consequences of not maintaining the accounting transactions.

\section{Islamic and Conventional Accounting Comparison:}

Islamic accounting is gverned by the rules and principles prescribed asper the rules of sharia'h, where as conventional accounting is governed by the man made principles purely based on the terms of trade and IFRS. Islamic does not dicate the specific form of accounting to be followed rather whtever form of accounting to be followed must not violate the governing principles of sharia in any way. Islamic accounting is having a religious base which is derived from the quran and sunnah where as, conventional accounting has a secular base which is based on the commercial law and fully man made principles. The users of accounting information are aslo different. The users of conventional accounting are the shareholders and creditirs. The users of Islamic accounting are the society at large. One of the priniple of Islamic accounting is to fair distribution of wealth among the society. It is evident Islamic accounting is not only accountable to the human being but also to the god. Islamic accounting makes sure that the certain elemnets like interest (in Arabic language - 'riba'), uncertainity/high speculation (in Arabic language - 'gharar') and gambling/betting (in Arabic language 'maysir') are not presented during the transaction.

\section{Recent Developments in Islamic Accounting:}

Islamic accounting continues to be at the growing stage. Still more and more research are to be carried on to develop accounting and ethical standards. Islamic economies are also developing alongside the conventional economies. Beacause conventional accounting standars are not able to meet the requirement of the objectives of the Islamic finance as namely the objective of social justice and socio economic objective. Despite the immense potential Islamic economies are still playing the second fiddle to the conventional economies. Because the Muslim world has been under the western colonisation for saveral years it has left so much social and cultutal influence on every aspect of life. The Muslim countries still have western influences. As far as accounting is concerned, Muslim countries till recently have been using the GAAP and IFRS developed by th ewestern world. It was from the global recession 2008 that the quest for establishing Islamic accounting standards increased and consequently (AAOIFI) Accounting and Auditing Organization for Islamic Financial Institutions and other organisations are working tirelessly to develop a separate accounting standards asper the sharia principles applicable for the IFI's.

\section{AAOIFI and its Role in Development of Islamic Accounting Standards for IFI's:}

Establishment of AAOIFI has been of the greatest milestone in the development of the Islamic financial institutions. AAOIFI is a bahrain based not for profit organisation mainly responsible for developing and issuing the accounting standards for Islamic Financial institutions across the globe. It has already issued more than 100 standards in the area of accounting, ethics and governanc to be compliant with the shariah standards internationally. If you look at the need and importance of accounting tandards for ther IFI's, AAOIFI has done a remarkable job. AAOIFI has around 200 international members coming from more than 45 countries. There has been the remarkable development in the area of reporting for the Islamic financial institutions and a lot of credit must go to the AAOIFI.

Muslim scholar unanimouly agree that reporting according to IFI's standards is an act of obeying God (napier 2009). Accountable to Almighty doesn't mean that you can do the wrongdoings here. It simply also means that Islamic financial institutions should report with utmost honestly and gain the faith of the shareholders and other stakeholders by by reporting with utmost honesty (Archwer and Karim 2007). Keeping in view of the uniqueness of transactions of Islamic financial institutions many scholars ( Archer and karim, 2007, kamla 2009 and Vinnicombe 2010) are of the opinin that they should adopt the standards developed by AAOIFI. They aslo argue that that the adopting the AAOIFi standards willnot improve the loyalty, reliability, transperancy and efficiency of the finacial staem,ents but rather it will aslo increase the chances of making the particular organisation as global organisation (Karim, 2001; Hussain, Islam, Gunasekaran, Maskooki, 2002). The growth of Islamic finance can be attributed to its transparent and ethical reporting and a lot of credit goes to the AAOIFI for this (Khan 2010). The standards developed by AAOIFI are based on the IFRS itself but only it deals with the issues which are in contradiction to the sharia standards (Kamla 2010).

\section{Conclusion and Recommendation:}

It has been observed that there was a need for a separate accounting standards for Islamic finacial institions (IFI'S) and with the establishment of AAOIFI it has been achieved. One of the limitation of the AAOIFI standards could be that it is mainly based on the IFRS. Bt it is comprehensive in its own way and complies with the sharia standards. Since AAOIFI can not enforce the adoption of its standards on the IFI's many organisations are still using IFRS asper their own convenience. There is a need for a regulating body to enforce the standards 
on the IFI's. because of lack consesnsus among the IFI's there is a confusion among the users and reliability of the statements are aslo questioned. There is a great deal of dissatisfaction among users of Islamic services regulated BY IFI's are merely labelled as Islamic products and confusion with regard to adoption of AAOIFI standards only increases this dissatisfaction. There is a need for the Islamic countries to come together and make it mandatory for the IFI's to adopt uniform accounting standards which are in accordance with the sharia srandards.

\section{References:}

Archer and Karim, R. A. A. (2007). Accounting standards for Islamic Financial Services in Handbook of Islamic Banking by Hassan, K. and Mervyn Lewis: Edward Elgar Publishing Limited.

Archer, S. \& Abid, N. (1996). International Accounting Regulations for Islamic Banks. New Horizon, 56, 3-6.

Cooke, T. E. and Wallace, R. (1990), "Financial disclosure regulation and its environment: A review and further analysis", Journal of Accounting and Public Policy, Vol. 9 No. 2, pp. 79-110.

Elliot, B. and Elliot, J. (2007), Financial Accounting and Reporting, Pearson Education Limited, England.

Kamla, R. (2009). Critical insights into contemporary Islamic accounting. Critical Perspectives on Accounting, 20, 921-932.

Karim, R. A. A. (2001). International accounting harmonization, banking regulation, and Islamic regulation. The International Journal of Accounting, 36, 169-193.

Khan, F. (2010). How 'Islamic is Islamic Banking? Journal of Economic Behavior \& Organization, 76, 805-820.

Maurer, B. (2002), "Anthropological and accounting knowledge in Islamic banking and finance: rethinking critical accounts", Journal of the Royal Anthropological Institute, Vol. 8 No. 4, pp. 645-667.

Napier, C. (2009). Defining Islamic accounting: current issues, past roots. Accounting History, 14 (1-2), 121-144.

Nobes, C. and Parker, R. (2012), Comparative International Accounting, Pearson Education Limited, Essex.

Trokic, Amela. (2015). Islamic Accounting; History, Development and Prospects. 10.13135/2421-2172/1043.

Vinnicombe, T. (2010). AAOIFI reporting standards: Measuring compliance, Advances in Accounting, incorporating Advances in International Accounting, 26, 55-65 